\title{
David Schneider, Historia współczesnej medycyny, renesans, wynalezienie chirurgii i rewolucja implantów, tł. G. kuczkiewicz, wyd. Znak, Kraków 2021, ss. 560, rec. Magdalena Paciorek
}

\section{DOI: $10.4467 / 12311960 \mathrm{MN} .21 .017 .15249$}

W bieżącym roku na rynku wydawniczym ukazała się monografia Davida Schneidera zatytułowana Historia wspótczesnej medycyny, renesans, wynalezienie chirurgii i rewolucja implantów w tłumaczeniu Grzegorza Łuczkiewicza, wydana przez krakowskie wydawnictwo Znak. Książka - licząca 560 stron, zaopatrzona w pełen aparat naukowy i liczne fotografie - od samego początku wzbudza zainteresowanie, jest bowiem inna od znanych nam prac syntetycznych poświęconych dziejom medycyny. Ta odmienność dotyczy nie tylko okresu, czyli historii współczesnej medycyny, ale także sposobu jej przedstawienia. Autor, z zawodu chirurg ortopeda, w gawędziarski sposób przedstawia najważniejsze aspekty medycyny współczesnej. Celem jego pracy jest potwierdzenie tezy, jaką autor stawia, że tak naprawdę nie ma w historii medycyny czy - szerzej ujmując - w historii nauki tzw. samotnych geniuszy. Każde odkrycie czy tzw. moment przełomowy w danej dyscyplinie nauki w rzeczywistości jest konsekwencją wcześniejszych prac, dążeń i małych odkryć poprzedników z różnych dziedzin nauki, przyrodników, chemików, farmaceutów, mechaników, konstruktorów itp. Zamysł autora w pełni się powiódł, choć niekiedy konieczność dopełnienia informacji na dany temat $\mathrm{z}$ innej dziedziny nauki może utrudniać przekaz głównego wątku. Zabieg ten wydaje się jednak konieczny choćby dla potwierdzenia swojej tezy.

I tak, Autor zaczyna swoją podróż od epoki renesansu, przywołując również czasy starożytne Hippokratesa i Galena, nie zapominając jednak o wcześniejszym rozkwicie medycyny arabskiej, podczas gdy w świecie cywilizacji zachodniej panować miał półmrok. Jednak współczesność dla Schneidera rozpoczyna się od odkrycia J. Gutenberga $\mathrm{w} X \mathrm{X}$ w., no bo gdyby nie było czcionki drukarskiej... W gawędziarski sposób autor omawia odkrycie Andreasa Vesaliusa, dokonania Abrożego Pare na polu walki, które dały początek rozwojowi współczesnej nauki. W kolejnych rozdziałach przedstawia postaci Williama Harveya, Williama i Johna Hunterów - wielkich badaczy anatomii ciała ludzkiego. Po to, by następnie przejść do odkrywców patologii, a zatem i twórców mikroskopu jako podstawowego przyrządu umożliwiającego poznanie mikroskopowe komórki. Przy okazji tej 
podróży w przeszłość czytelnik poznaje Giovanni Battistę Morgagniego, Rudolfa Virchowa i innych.

W kolejnych rozdziałach autor wkracza w świat odkryć zarazków, a zatem I. Semmmelweis, J. Lister, L. Pasteur czy R. Koch; antybiotyków P. Ehrlich, G. Domagk, A. Fleming, S. Waksman, A. Schatz czy rozwoju anestezji, bez której dalszy rozwój chirurgii nie miałby racji bytu. Odkrycia Crawforda Longa i Williamsa Mortona, Horacego Wellsa z użyciem podtlenku azotu, eteru, później chloroformu. Dalej odkrycia innych środków znieczulenia, tj. kokainy, nowokainy, pozwoliły na rozwój chirurgii planowej, tej miękkiej, brzusznej, jak i tej ortopedycznej, i w końcu chirurgii serca.

Kolejne rozdziały poświęcone zostały omówieniu systemu współczesnego szpitalnictwa amerykańskiego i podstawom jego funkcjonowania, a zatem ubezpieczeniom. Następnie kwestii legalizacji urządzeń medycznych, ich atestów, patentów; dotyczyło to również wszystkich produktów zarówno medycznych, jak i farmaceutycznych, w tym m.in. szczepionek, surowic, kwestii przetaczania krwi, aż wreszcie produkcji implantów. Temu ostatniemu zagadnieniu Autor poświęcił kolejne części swojej pracy. W rozdziale Rewolucja implantów czytelnik wkroczył we współczesność. To nie tylko implanty stomatologiczne czy popularne dzisiaj endoprotezy wykorzystywane w ortopedii, ale także rozruszniki serca, implantacje zastawek, stendy, implanty okulistyczne, protezy słuchowe, neurochirurgiczne zastawki, stymulatory rdzenia kręgowego itp. Autor w fachowy sposób przedstawia ich genezę i rozwój, a następnie dalsze doskonalenie produktów. Po lekturze rozdziałów autor zadaje sobie pytanie: co dalej? Jaka nas czeka przyszłość? Miniaturyzacja implantów, płucoserce, rewolucja genetyczna? Czy może cyborg? Pytanie to niech pozostaje bez odpowiedzi, bo kto może znać przyszłość...

Na zakończenie warto dodać, że książka zasługuje w pełni na uznanie. Warto ją polecić nie tylko medykom czy historykom medycyny, ale także studentom kierunków medycznych i doktorantom, a także wszystkim pasjonatom. 